-Journal Publications ・Research Consultancy

\title{
COMPARATIVE ANALYSIS OF WATER AND NANO FLUID IN \\ STHE USING COMPUTATIONAL FLUID DYNAMICS
}

DEEPAK KUMAR, HARDIAL SINGH \& SANJEEV SHARMA

Department of Mechanical Engineering, Amity University Haryana, Haryana, India

\begin{abstract}
In this current work, study has been conducted on the shell and tube heat exchanger. CFD was used to carry out the analysis of this heat exchanger. Fluent software was used to project the pressure distribution. The effectiveness of base fluid and nano fluid was simulated and compared. The base fluid used was water and nano fluid used for the analysis was $\mathrm{Al}_{2} \mathrm{O}_{3}$. Rate of heat transfer was inspected. It was established from the results that $\mathrm{Al}_{2} \mathrm{O}_{3}$ was more effective as compared to base fluid. The role of eddy viscosity had been also discussed.

KEYWORDS: STHE, Fluent, Pressure Distribution, ANSYS, Viscosity Distribution \& Heat.
\end{abstract}

Received: May 07, 2019; Accepted: May 27, 2019; Published: Jul 11, 2019; Paper Id.: IJMPERDAUG201983

\section{INTRODUCTION}

The shell-and-tube heat exchangers (STHE) are still the most prevalent class in work. As compared to others, STHE have high A /V ratio. They can handle high pressures. STHE consists of a cylindrical shell with bundles of tubes inside. One fluid passes inside the tubes and other fluid passes within space between the tubes and shell. STHE is shown in Figure 1.

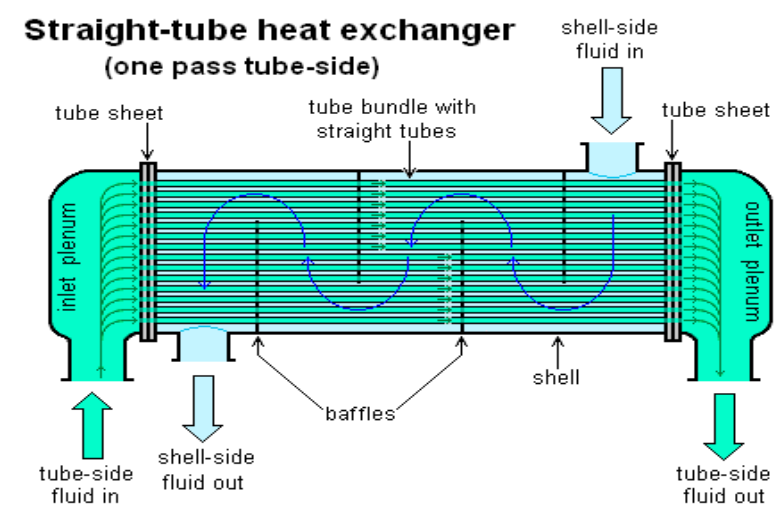

Figure 1: STHE

Nuntaphan et al. [2007] considered the result of the acclivity angle on the louvered fin and tube heat exchanger (LFTHE) in convection, which is free in nature. It was developed that the acclivity gradient plays an important place on the implementation of LFTHE. The execution of the heat exchanger is related with the interconnections between the louver, tube as well as acclivity angle. The heat transfer potential substantially reduces with ascent in the acclivity angle. This reduction in heat transfer potential is because of the hindrance of the vane and its backward dissipating heat movement against the rising air. However, at an acclivity inclination of 30 degree to 45 degree, a substantial improvement of heat transfer potential was observed. It happened because, 
substantial quantity of air was forwarded by the louver, resulting in "louver- directed" effect, as seen in convection which is forced in nature. Due to supplementary upsurge of the acclivity angle, the hindrance result is strong enough as to counteract the "louver-directed" process. In contrast with forced convection, the heat transfer potential reduced as the tube row increased. Gang Lei [2008] perpetrated quantitatively and innovatively the execution of a heat exchanger in the company of coiled obstruction. CFD procedure was used to reproduce the heat exchanger with coiled obstruction. The investigation was organized with hot oil on the side of shell and cool water on side of tube. They explored that the CFD forecasts could be counted on in the enactment of current geometric layout. Kumar, Jaya et al. [2008] perpetrated innovative and quantitative explorations on heat transfer in helically coiled heat exchangers considering conjoin heat transfer and thermal supported effects of heat transport media. HTC of the heat exchanger was deliberated using the Fluent 6.2. The CFD predictions were considerably good in agreement with the innovative outcomes within innovative erratum limits. Li and Wang [2010] conducted an innovative survey on the airside transfer of heat and drop of pressure attributes for $\mathrm{Br}$ - $\mathrm{Al}$ heat exchangers with multiple-area louvered vanes and smooth tubes. A sequence of pilot study was managed for heat exchangers with divergent numbers of louver area, at the air part $R_{e}$ of 400-600 based on the louver pitch. NTU method was used to examine the air-side thermal potential details. In this survey, the associations of the $j$ and $f$ elements were revealed depending on geometry parameters. Lemouedda et al. [2011] quantitatively examined the transfer of heat potential of serrated finned tubes by distorting the outmost part of the vane at divergent inclination and by adjusting the number of vane components/ period. CFD simulations were performed considering the compressible nature of flow and conjugate heat transfer for Reynolds numbers between 600 and 2600 i.e. the flow over the fins was considered to be laminar. Khaled et al. [2011] developed an analytical approach using the elementary calculations for representing transfer of heat in heat exchangers, to determine the thermal potential of air cooled cross-flow heat exchangers. A 2 - D computational code is also generated to assess the heat exchanger potential.

\section{OBJECTIVES}

- To study the pressure distribution using Fluent as a tool

- Comparative analysis of heat transfer using water and Nano fluid

\section{COMPUTATIONAL MODEL}

The computational model of STHE is shown in the figure below with inlet and outlet.

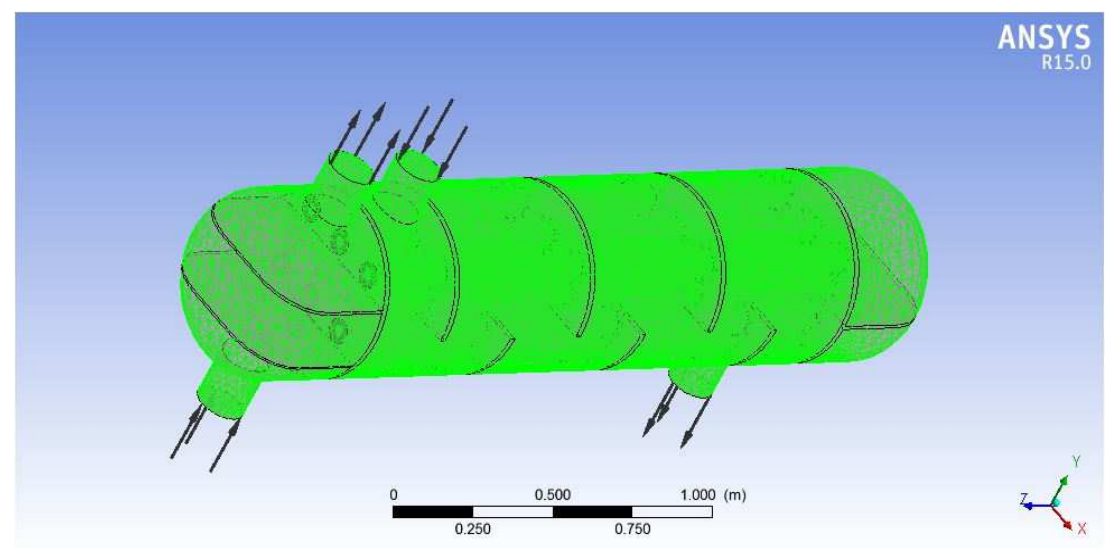

Figure 2: Computational Model of STHE 


\section{METHODOLOGY}

- ANSYS is used for the simulation of STHE. Geometry is drawn in solid works and simulation is performed in fluent.

- Geometry related to problem is identified

- Meshing is done which may be uniform or non uniform

- Outline the boundary conditions

- Start the simulation work.

- Analysis of the problem.

\section{Script File}

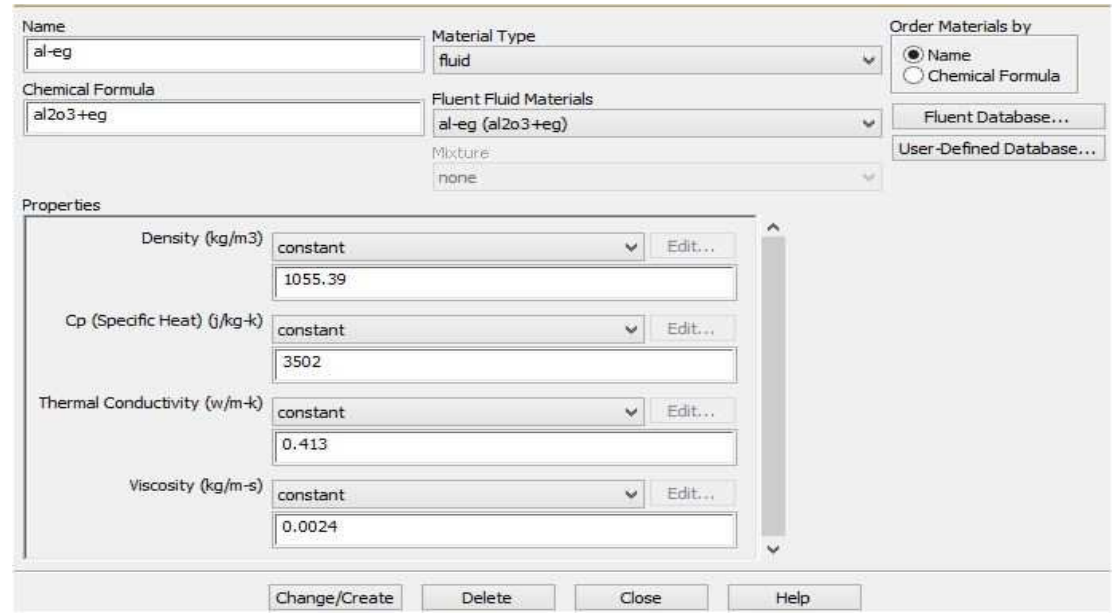

Figure 3: Input Properties for Aluminum Oxide $\left(\mathrm{Al}_{2} \mathrm{O}_{3}\right)$

\section{RESULTS AND DISCUSSIONS}

\section{Variation of Pressure}

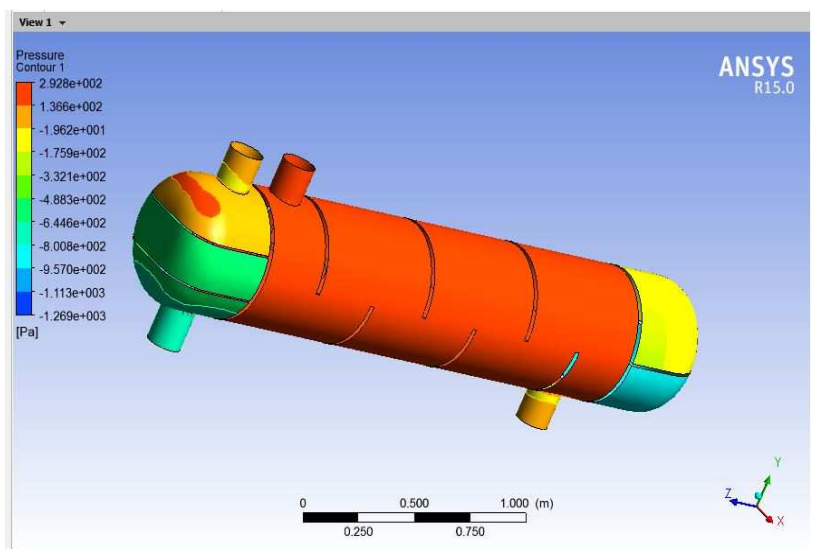

Figure 4: Pressure Arrangement across STHE (Water)

The pressure arrangement along the STHE (Water) is shown in the figure 4. The pressure at entrance of the hot fluid is $2.928 \mathrm{~Pa}$, and at the outlet is $1.759 \mathrm{~Pa}$. The pressure at the entrance of cold fluid is $1.962 \mathrm{~Pa}$ and at outlet it is 4.883Pa. 


\section{Variation of Eddy Viscosity}

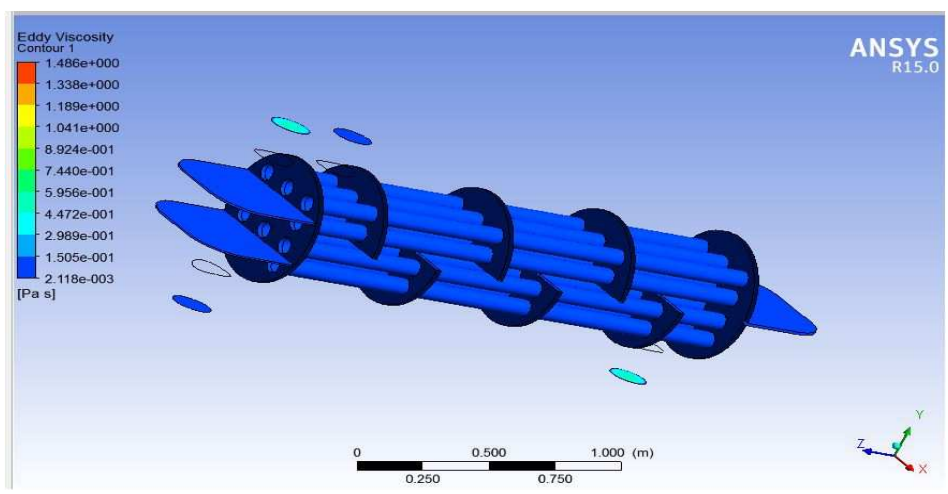

Figure 5: Eddy Viscosity Distribution across Heat Exchanger (Water)

The viscosity distribution along STHE (water) is shown in the figure 5. The viscosity at inlet of the hot fluid is $2.118 \mathrm{~Pa} \mathrm{~s}$, and at the outlet is $2.989 \mathrm{~Pa}$ s. The viscosity at the inlet of the cold fluid is $4.470 \mathrm{~Pa}$ s and at the outlet it is 2.118Pa s.

\section{Variation of Pressure}

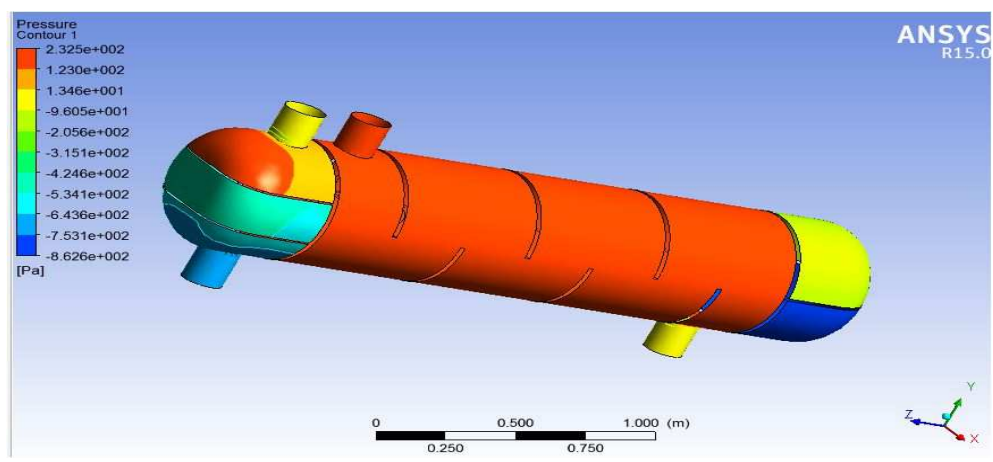

Figure 6: Pressure Arrangement across STHE (Nano-Fluid)

The pressure arrangement along STHE $\left(\mathrm{Al}_{2} \mathrm{O}_{3}\right)$ is shown in the figure 6 . The pressure at entrance of the hot fluid is $2.325 \mathrm{~Pa}$, and at outlet is $1.346 \mathrm{~Pa}$. The pressure at the entrance of the cold fluid is $1.392 \mathrm{~Pa}$ and at outlet it is $5.341 \mathrm{~Pa}$.

\section{Variation of Viscosity}

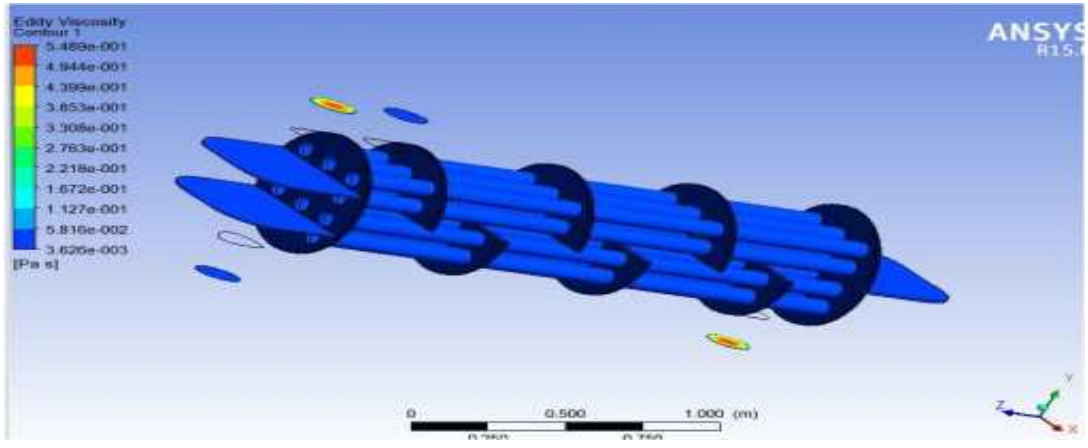

Figure 7: Eddy Viscosity Distribution across STHE (Nano-Fluid)

The viscosity distribution along STHE $\left(\mathrm{Al}_{2} \mathrm{O}_{3}\right)$ is shown in the figure 7 . The viscosity at the inlet of the hot fluid is $3.626 \mathrm{~Pa} \mathrm{~s}$, and at the outlet is $4.944 \mathrm{~Pa} \mathrm{~s}$. The viscosity at the inlet of the cold fluid is $4.399 \mathrm{~Pa}$ s and at the outlet it is 3.853 Pa s. 


\section{Output Results Comparison}

\section{Temperature}

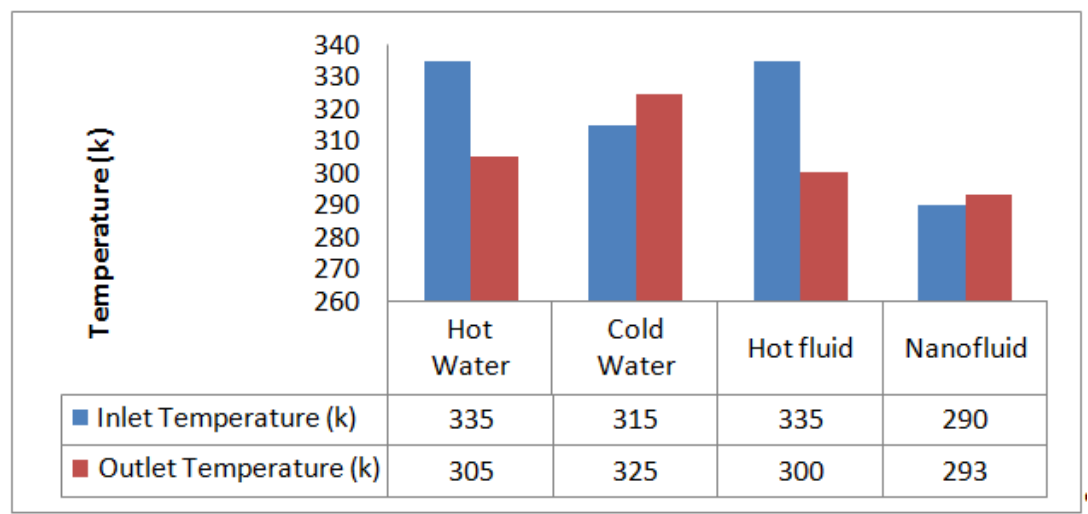

Figure 8: Temperature Differentiation for Water and $\mathrm{Al}_{2} \mathrm{O}_{3}$

Figure 8 shows the Temperature differentiation for water and $\mathrm{Al}_{2} \mathrm{O}_{3}$. The results show that the variance in temperature at entrance and the outlet is high in using nano fluid compared with the water.

\section{Pressure}

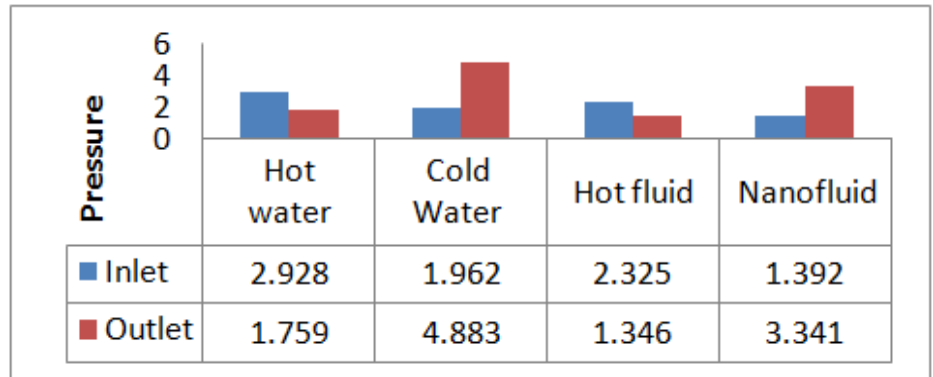

Figure 9: Pressure Differentiation between Water and $\mathrm{Al}_{2} \mathrm{O}_{3}$

Figure 9 shows the pressure variance between the water and $\mathrm{Al}_{2} \mathrm{O}_{3}$.

\section{Velocity}

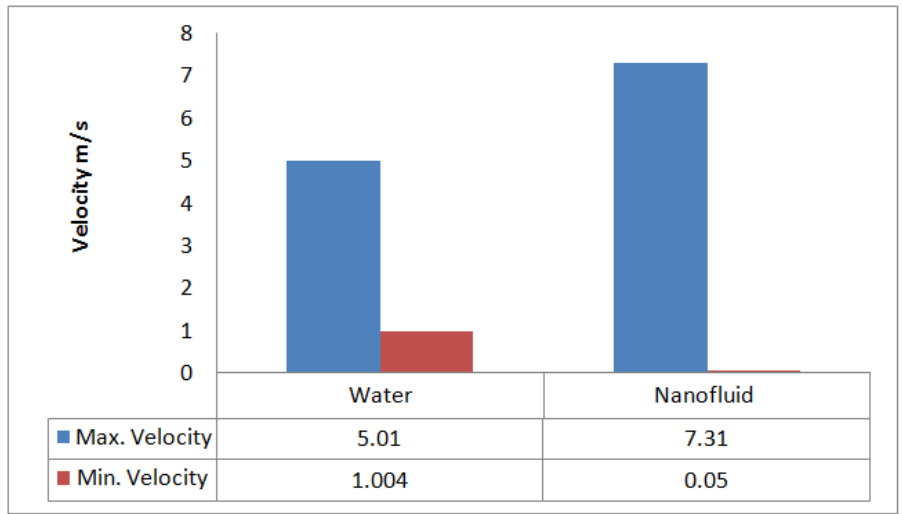

Figure 10: Velocity Differentiation between Water and $\mathrm{Al}_{2} \mathrm{O}_{3}$

Figure 10 shows the velocity variance between the water and $\mathrm{Al}_{2} \mathrm{O}_{3}$. The results show that the maximum velocity is obtained in using the nano fluids. 


\section{Viscosity}

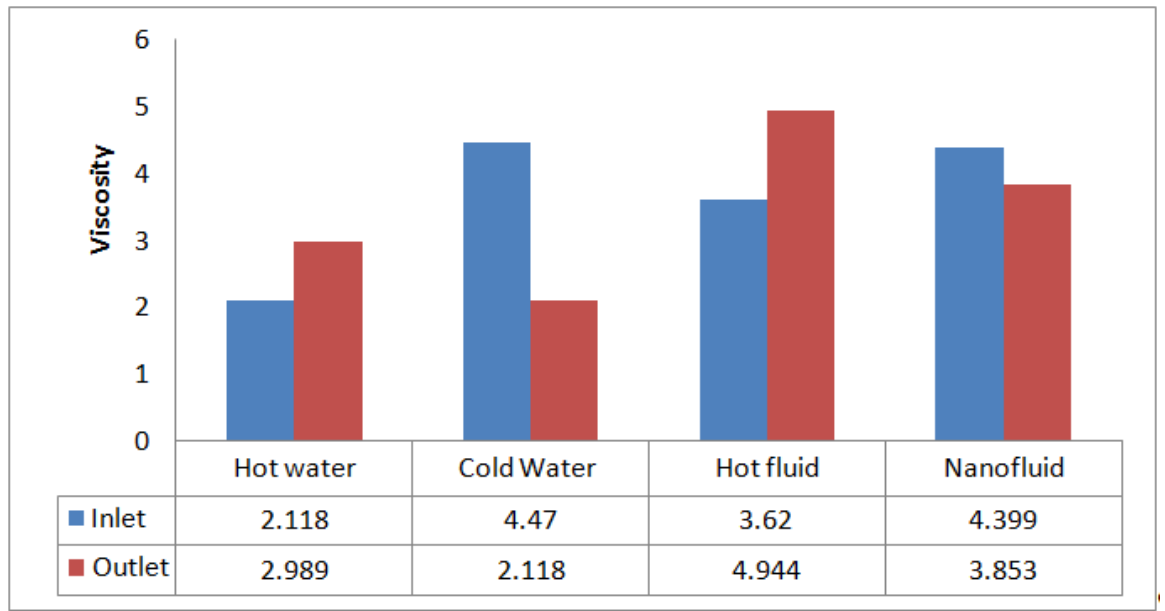

Figure 11: Viscosity Differentiation between Water and $\mathrm{Al}_{2} \mathrm{O}_{3}$

\section{Heat Transfer Rate}

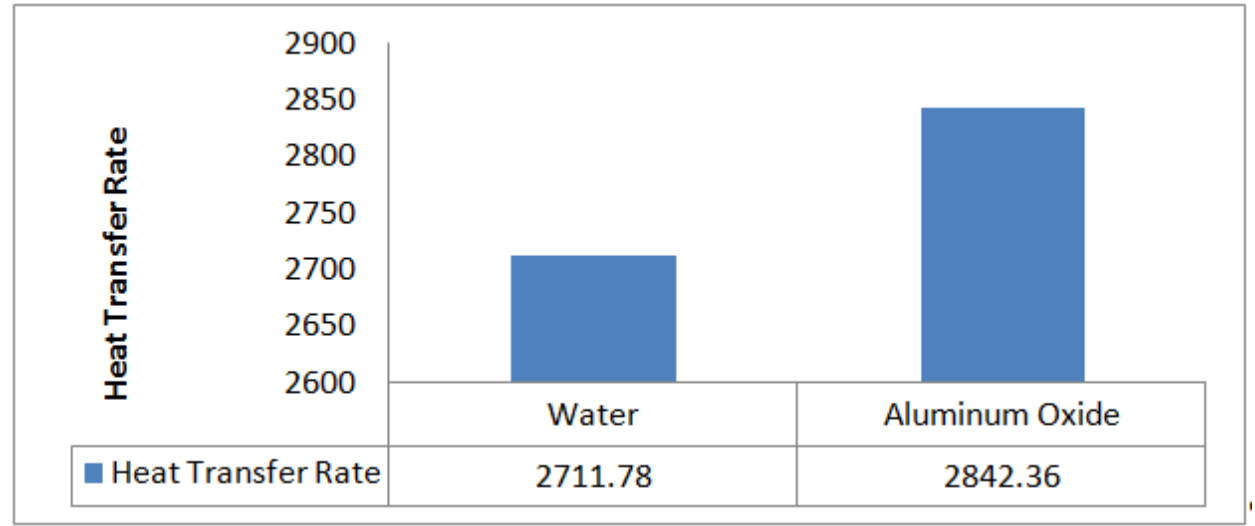

Figure 12: Heat Transfer Rate Comparison

\section{CONCLUSIONS}

The pressure distribution and rate of heat transfer is analyzed using Fluent in case of base fluid and nano fluid. It was found from the solutions that the heat carrying capacity of nano fluid is more in differentiation to base fluid. $\mathrm{So}_{2} \mathrm{Al}_{2} \mathrm{O}_{3}$ is having high effectiveness as compared to water. Hence, another scope for improvement is by using the different volume concentration of nano fluid.

\section{ACKNOWLEDGMENTS}

I thank our colleagues from Amity University, who provided insight and expertise that greatly assisted the research, although they may not agree with all of the interpretations/conclusions of this paper. 


\section{REFERENCES}

1. Kakaç, S., Liu, H. \& Pramuanjaroenkij, A., 2002. Heat exchangers: selection, rating, and thermal design. CRC press.

2. Kumar, R., Varma, H. K., Mohanty, B.\& Agrawal, K. N., 2002. Prediction of heat transfer coefficient during condensation of water and R-134a on single horizontal integral-fin tubes. International Journal of Refrigeration, 25(1), pp.111-126.

3. Belghazi, M., Bontemps, A., \&Marvillet, C., 2003. Experimental study and modelling of heat transfer during condensation of pure fluid and binary mixture on a bundle of horizontal finned tubes. International Journal of Refrigeration, 26(2), pp.214223.

4. Naphon, P., 2006. Heat transfer and pressure drop in the horizontal double pipes with and without twisted tape insert. International Communications in Heat and Mass Transfer, 33(2), pp.166-175.

5. OSMAN, H. B., 2012. Granular flow and heat transfer in a screw conveyor heater: a discrete element modeling study (Doctoral dissertation).

6. Xie, G., Zhang, F., Sundén, B., \& Zhang, W., (2014). Constructal design and thermal analysis of microchannel heat sinks with multistage bifurcations in single-phase liquid flow. Applied thermal engineering, 62(2), pp.791-802.

7. Lei, Y. G., He, Y. L., Li, R. \& Gao, Y. F., 2008. Effects of baffle inclination angle on flow and heat transfer of a heat exchanger with helical baffles. Chemical Engineering and Processing: Process Intensification, 47(12), pp.2336-2345.

8. Jayakumar, J. S., Mahajani, S. M., Mandal, J. C., Vijayan, P. K., \& Bhoi, R., 2008. Experimental and CFD estimation of heat transfer in helically coiled heat exchangers. Chemical engineering research and design, 86(3), pp.221-232.

9. Lemouedda, A., Schmid, A., Franz, E., Breuer, M., \& Delgado, A., 2011. Numerical investigations for the optimization of serrated finned-tube heat exchangers. Applied Thermal Engineering, 31(8-9), pp. 1393-1401.

10. Murase, T., Briggs, A., Wang, H. S., \& Rose, J. W., 2005. Condensation on a horizontal wire-wrapped tube. Journal of Heat transfer, 127(11), pp.1207-1213.

11. Briggs, A., Wang, H. S., Murase, T., \& Rose, J. W., 2003. Heat transfer measurements for condensation of steam on a horizontal wire-wrapped tube. Journal of Enhanced Heat Transfer, 10(4).

12. Chien, L. H., \& Hwang, H. L., 2012. An experimental study of boiling heat transfer enhancement of mesh-on-fin tubes. Journal of Enhanced Heat Transfer, 19(1).

13. Heris, S. Z., Esfahany, M. N., and Etemad, S., 2007. Experimental Investigation of Convective Heat Transfer of Al Nano fluids in Fully Developed Laminar Flow Regime. International Journal of Heat and Mass Transfer, 52(1-2), pp. 193-199.

14. Kim, D., Kwon, Y., Cho, Y., Li, C., Cheong, S., Hwang, Y., Lee, J., Hong, D., and Moon, S., 2009. Convective Heat Transfer Characteristics of Nano fluids under Laminar and Turbulent Flow Conditions. Current Applied Physics, 9(2), pp. 119-123.

15. Maïga, S. E. B., Nguyen, C. T., Galanis, N., and Roy, G., 2004. Heat Transfer Behaviors of Nano fluids in a Uniformly Heated Tube. Super lattices and Microstructures, 35(3-6), pp. 543-557.

16. Bianco, V., Chiacchio, F., Manca, O., and Nardini, S., 2009. Numerical Investigation of Nano fluids Forced Convection in Circular Tubes. Appl. Therm. Eng., 29(17-18), pp. 3632-3642.

17. Xuan, Y. and Roetzel, W., 2000. Conceptions for Heat Transfer Correlation of Nano fluids. International Journal of Heat and Mass Transfer, 43(19), pp. 3701-3707.

18. Pak, B. C., and Cho, Y. I., 1998. Hydrodynamic and Heat Transfer Study of Dispersed Fluids with Submicron Metallic Oxide Particles. Exp. Heat Transfer, 11(2), pp. 151-170. 
19. Wang, X., Choi, S. U. S., and Xu, X., 1999. Thermal Conductivity of Nano particle - Fluid Mixture. J. Thermophys. Heat Transfer, 13(4), pp. 474- 480.

20. Choi, S. U. S., Zhang, Z. G., Yu, W., Lockwood, F. E., and Grulke, E. A., 2001. Anomalous Thermal Conductivity Enhancement in Nano tube Suspensions. Appl. Phys. Lett., 79(14), pp. 2252-2254.

21. Jose M. Corberan and Jose Gonzalvez, 2002. Two-Phase Heat Transfer Analysis of Evaporators. Experimental Thermal and Fluid Science, 26(1), pp. 259-267.

22. Lee, H.J., and Lee. S.Y., 2001. Heat Transfer Correlation for Boiling Flows in Small Rectangular Horizontal Channels with Low Aspect Ratios. International Journal of Multiphase Flow, 27(1), pp. 2043-2062.

23. Ghosh, S. U. G. A. T. O., \& MILLER, A. (2013). Effect using turbulent flow of couple stress fluid in seven and thirteen axial grooves journal bearing. IJMPERD) ISSN, 209-222.

24. YasarIslamoglu and CemParmaksizoglu, 2003. The Effect of Channel Height on the Enhanced Heat Transfer Characteristics in a Corrugated Heat Exchanger Channel. Applied Thermal Engineering, 23(1), pp. 979-987.

25. Yanik.M..K and Webb.R.L., 2004. Prediction of Two-Phase Heat Transfer in a 4-Pass Evaporator Bundle Using Single Tube Experimental Data. Applied Thermal Engineering. 24(1), pp. 791-811.

26. Li, J., Wang, S., Cai, W. and Zhang, W., 2010. Numerical study on air-side performance of an integrated fin and microchannel heat exchanger. Applied Thermal Engineering, 30 (2), pp. 2738-2745.

27. Cui, J. and Tafti, D.K., 2002. Computations of flow and heat transfer in a three-dimensional multi-louvered fin geometry. International Journal of Heat and Mass Transfer, 45 (2), pp. 5007-5023.

28. Perrotin, T. and Clodic, D., 2004. Thermal-hydraulic CFD study in louvered fin and tube heat exchanger. International Journal of Refrigeration, 27 (3), pp. 422-432.

29. Khaled, M., Harambat, F. and Peerhossaini, H., 2011. Analytical and empirical determination of thermal performance of louvered heat exchanger-Effects of air low statistics. International Journal of Heat and Mass Transfer, Vol. 54, pp. 356-365.

30. Rashid, F., Dawood, K., \& Hashim, A. H. M. E. D. (2014). Maximizing of solar absorption by (TiO2-water) nanofluid with glass mixture. International Journal of Research in Engineering \& Technology, 2, 87-90.

31. Kim, M.H., Youn, B. and Bullard, C.W., 2001. Effect of inclination on the air-side performance of a brazed aluminum heat exchanger under dry and wet conditions. International Journal of Heat and Mass Transfer, Vol. 44, pp. 4613-4623.

32. Nuntaphan, A., Vithayasai, S., Kiatsiriroat, T. and Wang, C. C., 2007. Effect of inclination angle on free convection thermal performance of louver finned heat exchanger. International Journal of Heat and Mass Transfer, Vol. 50, pp. 361-366. 